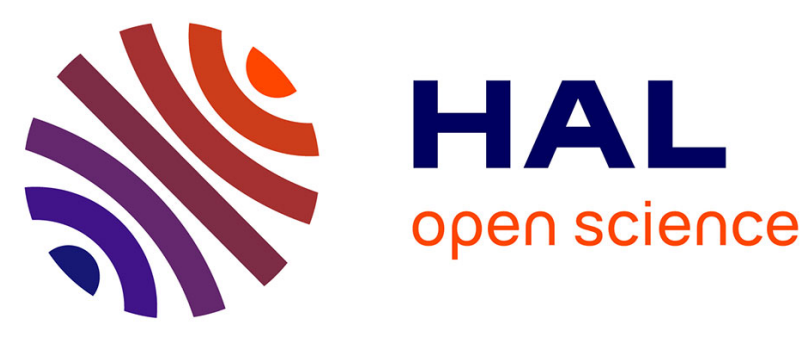

\title{
New insight into indium electrochemistry in a Tf2N-based room-temperature ionic liquid
}

Youssouf Traore, Sophie Legeai, Sébastien Diliberto, Guilhem Arrachart, Stéphane Pellet-Rostaing, Micheline Draye

\section{To cite this version:}

Youssouf Traore, Sophie Legeai, Sébastien Diliberto, Guilhem Arrachart, Stéphane Pellet-Rostaing, et al.. New insight into indium electrochemistry in a Tf2N-based room-temperature ionic liquid. Electrochimica Acta, 2011, 58, pp.532-540. 10.1016/j.electacta.2011.09.085 . hal-03558139

\section{HAL Id: hal-03558139 \\ https://hal.univ-lorraine.fr/hal-03558139}

Submitted on 4 Feb 2022

HAL is a multi-disciplinary open access archive for the deposit and dissemination of scientific research documents, whether they are published or not. The documents may come from teaching and research institutions in France or abroad, or from public or private research centers.
L'archive ouverte pluridisciplinaire HAL, est destinée au dépôt et à la diffusion de documents scientifiques de niveau recherche, publiés ou non, émanant des établissements d'enseignement et de recherche français ou étrangers, des laboratoires publics ou privés.

\section{(1) (1) $\$$}

Distributed under a Creative Commons Attribution - NonCommercial - NoDerivatives 44.0 


\title{
New Insight into Indium electrochemistry in a $\mathrm{Tf}_{2} \mathrm{~N}-$ based
}

\section{Room-Temperature Ionic Liquid}

Youssouf Traore $^{\mathrm{a}}$, Sophie Legeai ${ }^{\mathrm{b}, *}$, Sébastien Diliberto ${ }^{\mathrm{a}}$, Guilhem Arrachart ${ }^{\mathrm{c}}$, Stéphane Pellet-Rostaing ${ }^{\mathrm{c}}$, Micheline Draye $\mathrm{a}^{\mathrm{a}}$

${ }^{a}$ Laboratoire de Chimie Moléculaire et Environnement, Université de Savoie, Campus scientifique, 73376 Le Bourget du Lac Cedex, France

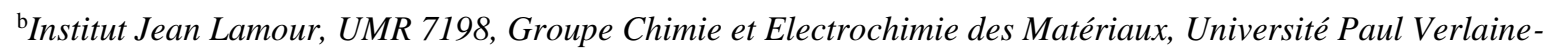
Metz, 1 bd Arago, 57078 Metz Cedex 3, France

${ }^{c}$ Institut de Chimie Séparative de Marcoule, CNRS/CEA/ENSCM, UMR 5257, Laboratoire Tri ionique par les Systèmes Moléculaires auto-assemblés, Bât. 406, Route de Marcoule, 30207 Bagnols sur Cèze, France

Y. Traore $\quad$ Youssouf.Traore1@etu.univ-savoie.fr $\quad$ Tel : +33-479-75-88-98 Fax : +33-479-75-86-74

S. Legeai $\quad$ sophie.legeai@univ-metz.fr $\quad$ Tel : +33-387-31-54-63 Fax : +33-387-31-54-60

S. Diliberto $\quad$ sebastien.diliberto@univ-metz.fr $\quad$ Tel : +33-387-31-54-60 Fax : +33-387-31-54-60

G. Arrachart guilhem.arrachart@cea.fr Tel : +33-466-79-15-68 Fax : +33-466-79-76-11

S. Pellet-Rostaing $\quad$ stephane.pellet-rostaing@cea.fr $\quad$ Tel : +33-466-33-93-08 Fax : +33-466-79-76-11

M. Draye $\quad$ micheline.draye@univ-metz.fr $\quad$ Tel : +33-479-75-88-59 Fax : +33-479-75-86-74

\begin{abstract}
In this paper we first present the synthesis and the physicochemical properties of low hygroscopic piperidinium-based ionic liquids that allow performing electrodeposition without the need of a glove box. A deep analytical study of the electrochemical system $\operatorname{In}(\mathrm{III}) / \operatorname{In}(0)$ in a 1-butyl-1-ethylpiperidinium bis(trifluoromethylsulfonyl)imide electrolyte $\left(\mathrm{BEPipTf}_{2} \mathrm{~N}\right)$ is then described. Troublesome aspects of using chloride metallic precursors in $\mathrm{Tf}_{2} \mathrm{~N}$-based electrolytes are highlighted using cyclic votammetry and stripping experiments. Indeed, voltammograms reveal a complex electrochemical behaviour and several cathodic and anodic signals that can be attributed to the formation of indium chlorocomplexes during the scan, due
\end{abstract}


to changes of concentrations ratio $\left[\mathrm{Cl}^{-}\right] /[\mathrm{In}(\mathrm{III})]$ of interfacial species during $\mathrm{In}(\mathrm{III})$ reduction reaction. $\operatorname{In}(\mathrm{III}) / \operatorname{In}(0)$ electrochemical system and metallic indium electrodeposition in a chloride-free electrolyte is then presented. The use of a chloride-free electrolyte leads to an improvement of electrodeposits morphology and to an increase in faradic yield from $33 \%$ to $85 \%$.

Keywords: piperidinium, ionic liquid, indium, electrodeposition

\section{Introduction}

Indium electrochemical deposition (ECD) is of great interest for the production of thin film semiconducting compounds (InSb, InAs, $\left.\mathrm{Cu}(\mathrm{In}, \mathrm{Ga})(\mathrm{S}, \mathrm{Se})_{2} \ldots\right)$ that are widely used in electronic and optoelectronic devices (detectors, laser, photovoltaics, light emitting diodes). ECD of indium-containing compounds in aqueous media has been extensively reported in the literature [1,2], pointing out that deposition efficiency is limited by $\mathrm{H}^{+}$reduction.

Low melting point ionic liquids or room-temperature ionic liquids (RTILs) are a new class of non aqueous solvents considered as promising electrolytes for ECD of high quality thin films since in this media hydrogen evolution does not occur [3-9]. They are liquid at roomtemperature or even below and they are characterized, in particular, by good ionic conductivities and wide electrochemical windows [10]. Two main families of RTILs are commonly used for ECD purposes: halide - based compounds, also called first generation RTILs, and second generation « air and water stable » RTILs. Numerous examples on the use of first generation RTILs for the ECD of single metals and alloys have been reported [11]. However, these chloroaluminate RTILs, combining aluminum chloride and dialkylimidazolium or dialkyl-pyridinium chloride, are highly hygroscopic and moisture exposure must be avoided by working in a glove box. The use of RTILs drastically increased since 
Wilkes et al. reported in 1992 the first air and moisture stable RTILs, called second generation RTILs, with either tetrafluoroborate or hexafluorophosphate as anions [12]. More recently, RTILs containing anions such as tri-fluoromethanesulfonate, bis(trifluoromethanesulfonyl)imide or tris(trifluoromethanesulfonyl)methide, were synthesized and received much attention because of their low viscosity, low hygroscopy and low reactivity against moisture [13]. However, currently developed and commercialized electrolytes must still be used in dry atmosphere for ECD applications and thus could not be considered as viable electrolytes by electroplating industries.

Moreover, contrary to the common belief, second generation RTILs are not "supersolvents" in which all kinds of materials can be dissolved easily. In fact, due to the poor solvating power of these RTILs composed of weakly coordinating anions, and to their modest polarity, the solubility of inorganic ionic compounds in second generation RTILs is very low excepted using chloride salts. However, the introduction of chloride ions in electroplating baths leads to undesirable chlorine gas evolution at the anode during ECD, increases hygroscopic character of the RTIL and leads in some cases to complex electrochemical behaviors.

ECD of In has been recently studied in an air and moisture stable RTIL, using a chloride salt as indium cation source [14]. In these conditions, $\operatorname{In}(\mathrm{III}) / \operatorname{In}(0)$ electrochemical system is far from simple, implying several reduction steps that are difficult to explain and lead to complex optimisation of ECD experimental parameters for high quality films synthesis. Moreover, in this previous work, experiments were carried out in highly restrictive conditions, namely in a glove box with water and oxygen concentration levels below $1 \mathrm{ppm}$. Indeed, the electrolytic solutions used, consisting in a 1-butyl-1-methylpyrrolidinium bis(trifluoromethylsulfonyl)imide $\left(\mathrm{BMPTf}_{2} \mathrm{~N}\right)$ RTIL containing $\mathrm{InCl}_{3}$ as metallic precursor, is too hygroscopic to perform ECD experiments in ambient atmosphere. 
In this paper, we first relate the synthesis and some physico-chemical properties of new low hygroscopic piperidinium - based RTILs. We then present a detailed study of the electrochemical behavior of $\mathrm{InCl}_{3}$ in the most convenient RTIL for $\mathrm{In}(0)$ ECD, 1-butyl-1ethyl-piperidinium bis(trifluoromethylsulfonyl)imide $\left(\mathrm{BEPipTf}_{2} \mathrm{~N}\right)$. The strong influence of $\mathrm{Cl}^{-}$ions on $\operatorname{In}(\mathrm{III}) / \operatorname{In}(0)$ electrochemical system is highlighted. Finally, some results concerning $\operatorname{In}(0)$ ECD using an indium soluble anode as In(III) precursor are compared to those obtained with an $\mathrm{InCl}_{3}$ - containing RTIL.

\section{Experimental}

Ionic liquids were prepared according to the procedure modified from the published report of A. Triolo et al. [15]. Briefly, nitrogen based heterocycle yielded the corresponding ammonium salt by reaction with alkyle bromide. Bromide anion was then replaced by bis(trifluoromethylsulfonyl)imide $\left(\mathrm{Tf}_{2} \mathrm{~N}^{-}\right)$by vigorous stirring of the alkylammonium bromide with aqueous solution of lithium bis(trifluoromethylsulfonyl)imide $\left(\operatorname{LiTf}_{2} \mathrm{~N}\right.$, Solvionic, $99+\%)$. After metathesis was finished ionic liquid was extracted with dichloromethane (Sigma Aldrich, >99.5\%) and then dried under reduced pressure for 3 hours. Synthesized ionic liquids were characterized by Nuclear Magnetic Resonance (NMR) analysis (Bruker Spectrospin DRX 300 MHz Ultrashield).

The density, the viscosity and the conductivity of RTILs were determined as function of water content which was determined by Karl Fischer coulometric titration (Metrohm 831KF coulometer) using Hydranal 34843 Coulomat AG-H (Fluka) as titrant.

The density measurements were performed with a thermo-regulated digital densimeter DSA 5000 (Anton Paar). The apparatus measures densities using an oscillating U-tube at an accuracy of $0.00001 \mathrm{~g} / \mathrm{cm}^{3}$ and temperature controlled with an accuracy of $0.001^{\circ} \mathrm{C}$. 
All measurements were conducted at $20.005 \pm 0.004^{\circ} \mathrm{C}$; the density is calculated from the quotient of the period of oscillations of the U-tube and the reference oscillator: density $=\mathrm{KA}$ $x \mathrm{Q}^{2} \mathrm{x} \mathrm{f}_{1}-\mathrm{KB}+\mathrm{f} 2$, where $\mathrm{KA}, \mathrm{KB}$ are constants from the apparatus, $\mathrm{Q}$ the quotient of the period of oscillation of the U-tube divided by the period of oscillation of the reference oscillator and $\mathrm{f}_{1}, \mathrm{f}_{2}$ correction terms for temperature, viscosity and nonlinearity.

All rheological measurements were performed on an automated microviscosimeter AMVn (Anton Paar). The apparatus measures viscosities in a $0.3-2500 \mathrm{mPa} . \mathrm{s}$ range using the rolling ball/falling ball principle which consist of the measurement of a ball rolling time in a diagonally mounted glass capillary filled with the sample. Ball rolling time was measured at an accuracy of $0.002 \mathrm{sec}$ with a temperature controlled with an accuracy of $0.001 \mathrm{C}$.

All measurements were conducted at $20.00^{\circ} \mathrm{C}$ with a $70^{\circ}$ inclination angle of the capillary, the dynamic viscosity $\eta$ is calculated using the following formula $\eta=K_{1} \times\left(\rho_{K}-\rho_{P}\right) \times t_{1}$ where $\mathrm{K}_{1}$ is the calibration constant of the measuring system, $\rho_{K}$ the ball density, $\rho_{P}$ the density of the measured sample and $t_{1}$ the ball rolling time.

Conductivities of RTILs were measured using a Tacussel électronique conductimeter/resistivitimeter CDRV62 using a platinum 2-electrodes cell (Materials Mates). The cell was calibrated with $5 \times 10^{-3}$ to $3.3 \times 10^{-2} \mathrm{KCl}$ solutions and the data were recorded at a frequency of $62 \mathrm{~Hz}$.

The solubility of water in the RTILs was determined by Karl Fischer coulometric titration after RTILs contact with distilled water. The water content of water-saturated RTILs in equilibrium with water was measured by mixing water and each RTIL for $24 \mathrm{~h}$. After that, the two-phase system was centrifuged and RTIL water content was measured.

Electrochemical experiments were carried out using a PGP201 potentiostat (Radiometer Copenhagen) and a Tacussel Electronique potentiostat (101T and PJT24-1). Before electrochemical experiments, the electrolytic solution was deaerated and dried down to water 
contents below 50 ppm by dry Ar bubbling. In(III) solutions were prepared whether by dissolution of $\mathrm{InCl}_{3} .4 \mathrm{H}_{2} \mathrm{O}$ (Sigma Aldrich, 97\%) or by electrochemical potentiostatic dissolution of an indium soluble anode (Alfa Aesar, 99.99\%) in the selected ionic liquid at ambient temperature. All experiments were performed at $60^{\circ} \mathrm{C}$ to lower RTILs viscosity and increase mass transport. Electroanalytical studies were carried out using a conventional threeelectrode electrochemical cell, with a platinum disk $\left(19.6 \mathrm{~mm}^{2}\right)$ as working electrode, a glassy carbon as counter electrode and an AgCl-covered Ag wire (Alfa Aesar 99,999\%) as pseudoreference electrode. Square plates of Pt (Goodfellow, Lille, France, 99.99\%, area $25.0 \mathrm{~mm}^{2}$ ) were used as substrates for the electrodeposition of indium. Electrodeposition was achieved by controlled potential electrolysis in steadily stirred BEPipTf ${ }_{2} \mathrm{~N}$ containing $\mathrm{In}(\mathrm{III})$. Before the electrochemical experiments were carried out, the working electrode was polished with SiC abrasive papers and $1 \mu \mathrm{m}$ diamond paste, and then soaked in deionized water and acetone. After electrodeposition, the indium-coated Pt-square plate electrodes were immediately transferred from the electrodepositing baths into acetone to remove the residual RTIL.

The surface morphology and grain size of the deposits were determined using a scanning electron microscope (FEG-SEM) (Philips XL30), provided with an energy dispersive spectrometry (EDS) detector. Structural characterizations were conducted by X-ray diffraction (XRD) using a Bruker diffractometer (D8 Advance, $\mathrm{Cu} \mathrm{K} \alpha_{1}$ radiation).

ECD faradic yields were determined by Atomic Absorption Spectrometry (Varian AA240FS) after chemical dissolution of the deposits in $3 \mathrm{M} \mathrm{HNO}_{3}$.

\section{Results and Discussion}

\subsection{Physicochemical properties of 1,1-dialkyl-PipTf 2 N RTILs}


Few literature reports deal with piperidinium-based RTILs because of their little commercial availability [16] ${ }^{1}$. However, their physicochemical properties can be compared to more extensively used pyrrolidinium- and imidazolium-based RTILs [10,16-21].

The density, electrochemical stability, conductivity and viscosity of several 1,1-dialkylPipTf $_{2} \mathrm{~N}$ RTILs as well as the solubility of water in these solvents are presented in Table 1 and compared to results obtained with imidazolium and pyrrolidinium-based RTILs (our results and literature data). As the density, the conductivity and the viscosity of ionic liquids can be affected by water impurities, values are reported in Table 1 along with corresponding RTIL water content in italics.

Table 1: RTILs physicochemical properties

Physicochemical properties determined in this work are in good agreement with literature data, when available. Results obtained for cathodic stability cannot be compared to literature data as these latter refer to other reference electrode devices. Cathodic stability and water solubility values obtained in this work follow the order BMITf $_{2} \mathrm{~N}<$ BMPyrrolTf $_{2} \mathrm{~N} \sim$ BMPipTf $_{2} \mathrm{~N} \sim$ BEPipTf $_{2} \mathrm{~N} \sim$ MOPipTf $_{2} \mathrm{~N} \sim<$ EOPipTf $_{2} \mathrm{~N}$. It appears then that all piperidinium-based RTILs tested present a wider electrochemical window and a lower hygroscopic character than other RTILs under consideration. It is commonly admitted that RTILs based on saturated-ring cations, like pyrrolidinium or piperidinium cations, present higher cathodic stability than unsaturated-ring cations, like imidazolium or pyridinium-based cations as well as octyl-substituted cations compared to butyl-substituted cations [10]. However, piperidium ring lead to more viscous and consequently less conductive RTILs 
compared to imidazolium or pyrrolidinium similar compounds. Finally, increasing cations alkyl chain length also leads to a decrease in conductivity of RTILs mainly due to an increase in viscosity, as commonly observed [10].

The best compromise between cathodic stability, conductivity and hygroscopic character appears to be BEPipTf $2 \mathrm{~N}$, and this RTIL was selected for the further studies. According to Table 1, BEPipTf $f_{2} \mathrm{~N}$ appears to be hygrophobic enough to work without the need of a glove box.

\subsection{Electrochemical behavior of $\mathrm{InCl}_{3}$ - containing electrolytes}

Figure 1 shows a typical cyclic voltammogram on $\mathrm{Pt}$ working electrode in $\mathrm{BEPipTf}_{2} \mathrm{~N}$ containing $0.1 \mathrm{M} \mathrm{InCl}_{3}$. It appears that the cyclic voltammogram is quite complex: several cathodic $\left(c_{1}-c_{5}\right)$ and anodic $\left(a_{1}-a_{5}\right)$ processes can be observed in the whole potential range tested. In order to elucidate the complete voltammogram, several experiments were undertaken by cyclic voltammetry and potentiostatic deposition followed either by anodic stripping or by XRD/SEM-EDS analysis of corresponding deposits.

Figure 1: Cyclic voltammograms recorded on platinum in BEPipTf ${ }_{2} \mathrm{~N}$.Scan rate $5 \mathrm{mV} / \mathrm{s}$. T $=60^{\circ} \mathrm{C}$.

3.2.1. Electrodeposition of In on Pt square plates and surface analysis of potentiostatic deposits 
1 hour potentiostatic deposition experiments were realised for several potential values, corresponding to $\mathrm{c}_{1}-\mathrm{c}_{5}$ peaks on platinum square electrodes. XRD patterns confirm the presence of metallic In for potential values lower than $200 \mathrm{mV}$ vs $\mathrm{AgCl} / \mathrm{Ag}$. Figure 2 shows a typical XRD pattern of $\operatorname{In}(0)$ deposits obtained at $\mathrm{E}_{\mathrm{dep}}=-920 \mathrm{mV}$ vs $\mathrm{AgCl} / \mathrm{Ag}$.

Figure 2: XRD pattern of an indium deposit on a platinum substrate. BEPipTf $2 \mathrm{~N}+\mathrm{InCl}_{3} 0.1$ M. $\mathrm{E}_{\mathrm{dep}}=-920 \mathrm{mV}$ vs $\mathrm{AgCl} / \mathrm{Ag}, \mathrm{t}_{\mathrm{dep}}=1 \mathrm{~h} . \mathrm{T}=60^{\circ} \mathrm{C}$.

SEM-EDS analysis revealed that $c_{1}, c_{2}$ and $c_{4}$ applied potentials only lead to low amounts of In(0) on the electrode and that only $c_{5}$ peak corresponds to bulk deposition. This result was already observed by S. Zein el Abedin et al. [14], who supposed that $\mathrm{c}_{1}$ to $\mathrm{c}_{4}$ peaks may correspond to multiple UPD/Pt-alloying processes, but this hypothesis was neither confirmed nor denied by detailed experimental electrochemical investigations. Moreover, the absence of metallic indium deposition between $c_{3}$ and $c_{4}$ is quite surprising. This behavior is drastically different from what was previously published. Indeed, very simple voltammetric curves with only single electrochemical signals were recorded using other substrates (Mo [22,23], glassy carbon [24-26], $\mathrm{Hg}[1,27], \mathrm{In}[1,28]$ ) and other solvents (high temperature molten salts $[23,24,28]$, RTILs $[22,25]$ or aqueous medium $[1,27]$.

\subsubsection{Detailed voltammetric study of In(III) in BEPipTf ${ }_{2} \mathrm{~N}$}


In order to get a deeper understanding of $\operatorname{In}(\mathrm{III}) / \operatorname{In}(0)$ electrochemical system in our electrolyte, a detailed voltammetric study was undertaken. First of all, to identify possible alloying processes with Pt substrate, the voltammogram obtained on Pt was compared to a cyclic voltammogram performed using a stainless steel working electrode (Figure 3). Using stainless steel, anodic potential windows is limited by electrode oxidation and consequently, $\mathrm{a}_{1}$ and $\mathrm{a}_{2}$ peaks could not be studied.

Figure 3: Cyclic voltammograms recorded in BEPipTf $_{2} \mathrm{~N}$ containing $0.1 \mathrm{M} \mathrm{InCl}_{3}$ on platinum and stainless steel. Scan rate $5 \mathrm{mV} / \mathrm{s} . \mathrm{T}=60^{\circ} \mathrm{C}$.

Cyclic voltammograms present roughly the same characteristics using both electrodes, except $\mathrm{c}_{1}$ signal which is not observed on steel. According to this observation, only $\mathrm{c}_{1}$ signal recorded on platinum substrate might be attributed to an In-Pt alloying process.

Voltammetric experiments by varying cathodic reversal potentials were then carried out using the Pt electrode, in order to study the other electrochemical signals (Figure $4 \mathrm{~b}-\mathrm{e}$ ). The complete voltammogram is reminded as Figure 4a.

Figure 4: Cyclic voltammograms recorded on platinum in BEPipTf $_{2} \mathrm{~N}$ containing $0.1 \mathrm{M}$ $\mathrm{InCl}_{3}$ with different reversal potentials. Scan rate $5 \mathrm{mV} / \mathrm{s} . \mathrm{T}=60^{\circ} \mathrm{C}$. 
When the scan is reversed just after peak $\mathrm{c}_{1}$ at $+50 \mathrm{mV}$ vs $\mathrm{AgCl} / \mathrm{Ag}$ (Figure 4e), two oxidation peaks, $\mathrm{a}_{1}$ and $\mathrm{a}_{2}$, are observed during the return scan. According to previous results (Figure 2), these anodic peaks might result from an In-Pt alloying process occurring at $\mathrm{c}_{1}$.

Decreasing cathodic potentials down to $-100 \mathrm{mV}$ vs $\mathrm{AgCl} / \mathrm{Ag}$, a new anodic peak a3 appears during the reverse scan, which intensity increases when decreasing reversal potential (Fig 4e). The electrochemical signal $c_{2}$ can then be attributed to the deposition of metallic indium. Complementary potentiostatic experiments were undertaken at $-100 \mathrm{mV}$ vs $\mathrm{AgCl} / \mathrm{Ag}$ for several deposition times, followed by anodic stripping using linear voltammetry (Figure 5a). The results obtained confirmed the hypothesis of $c_{2}$ corresponding to $\operatorname{In}(0)$ deposition and $a_{3}$ corresponding to elemental In stripping.

Surprisingly, by further decreasing the reversal potential down to $-500 \mathrm{mV}$ vs $\mathrm{AgCl} / \mathrm{Ag}$, the intensity of $a_{3}$ anodic peak decreases (Figure 4d). Simultaneously, $a_{1}$ increases with potential switching getting more cathodic. Potentiostatic deposition at $\mathrm{c}_{3}$ peak potential followed by anodic stripping was also performed for several deposition times. The results obtained confirm the decrease of $\mathrm{a}_{3}$ anodic peak and the increase of $\mathrm{a}_{1}$ with increasing deposition time (Figure 5b). One can also notice the shape of $c_{3}$ peak, characteristic of a surface reaction limited by a finite amount of matter, that suggests that $\operatorname{In}(0)$ previously deposited might undergo an electrochemical transformation (surface rearrangement, second In-Pt alloying step...). At this date, none of experiments performed allow us to make any hypothesis concerning the electrochemical reaction corresponding to $c_{3}$ cathodic peak. 
Figure 5: Voltammograms recorded during anodic stripping of indium in $\mathrm{BEPipTf}_{2} \mathrm{~N}$ containing $0.1 \mathrm{M} \mathrm{InCl}_{3}$, for different deposition charge values. Platinum substrate. Scan rate 5 $\mathrm{mV} / \mathrm{s} . \mathrm{T}=60^{\circ} \mathrm{C}$.

a: $\mathrm{E}_{\text {dep }}=-100 \mathrm{mV}$ vs $\mathrm{AgCl} / \mathrm{Ag}$

b: $\mathrm{E}_{\mathrm{dep}}=-200 \mathrm{mV}$ vs $\mathrm{AgCl} / \mathrm{Ag}$

According to Figure $4 \mathrm{~b}$ and $4 \mathrm{c}, \mathrm{c}_{5}$ cathodic peak that was previously attributed to bulk deposition of $\operatorname{In}(0)$ thanks to XRD analysis, is related to three anodic stripping peaks: $a_{3}, a_{4}$ and $a_{5}$. The link between $c_{5}$ and $a_{3}$ is in agreement with previous observations attributing $a_{3}$ signal to $\operatorname{In}(0)$ stripping (Figure $4 \mathrm{e}$ ). As shown on Figure $4 \mathrm{~b}$, a3 peak is only observed for switching potential lower than $-920 \mathrm{mV}$ vs $\mathrm{AgCl} / \mathrm{Ag}$ and its peak current then increases with switching potential getting more cathodic. Conversely, a4 and as peak currents reach constant values for potentials lower than $-1200 \mathrm{mV}$ vs $\mathrm{AgCl} / \mathrm{Ag}$.

In order to confirm voltammetric results, potentiostatic experiments were undertaken at $c_{5}$ peak potential for increasing deposition times, followed by anodic stripping using linear voltammetry. Results obtained are presented in Figure 6a.

Figure 6a: Voltammograms recorded during anodic stripping of indium in $\mathrm{BEPipTf}_{2} \mathrm{~N}$ containing $0.1 \mathrm{M} \mathrm{InCl}_{3}$, for different deposition charge values. Platinum substrate. Scan rate 5 $\mathrm{mV} / \mathrm{s} . \mathrm{T}=60^{\circ} \mathrm{C} . \mathrm{E}_{\mathrm{dep}}=-920 \mathrm{mV}$ vs $\mathrm{AgCl} / \mathrm{Ag}$. 
As can be observed, only $a_{3}$ peak grows significantly with deposition time meaning that $a_{3}$ signal can be related to the anodic "bulk" dissolution of $\operatorname{In}(0)$ previously deposited. Figure $6 \mathrm{~b}$ presents anodic charges $\mathrm{Qa}_{3}$, Qa4 and Qa5, corresponding respectively to peaks $\mathrm{a}_{3}, \mathrm{a}_{4}$ and $\mathrm{a}_{5}$, as well as $\mathrm{Q}_{\mathrm{a} \text { total }}=\mathrm{Qa}_{3}+\mathrm{Qa}_{4}+\mathrm{Qa}$, as a function of cathodic charge $\mathrm{Q}_{\mathrm{c}}$ related to potentiostatic deposition.

Figure 6b: Anodic charges corresponding to potentiodynamic stripping of indium (voltammograms presented in Fig. 6a) as a function of cathodic charge related to potentiostatic deposition. BEPipTf $\mathrm{Tf}_{2} \mathrm{~N}$ containing $0.1 \mathrm{M} \mathrm{InCl}_{3}$.Platinum substrate. $\mathrm{T}=60^{\circ} \mathrm{C}$. $\mathrm{E}_{\text {dep }}=-920 \mathrm{mV}$ vs AgCl/Ag.

$\mathrm{Q}_{\mathrm{a}}$ total grows linearly with $\mathrm{Q}_{\mathrm{c}}$, meaning that the three anodic peaks under consideration can be related to anodic dissolution of $\operatorname{In}(0)$ deposited during the potentiostatic step. Considering separately anodic charges Qa3, Qa4 and Qa5, one can observe that Qa increases linearly with $\mathrm{Q}_{\mathrm{c}}$ for deposition times longer than 2 min, whether Qa4 and Qa5 remains constant in the same range of deposition time. On the other hand, for deposition times shorter than 2 minutes, the inverse behavior is observed: $\mathrm{Qa}_{4}$ and $\mathrm{Qa}_{5}$ increase linearly with $\mathrm{Q}_{\mathrm{c}}$, whereas $\mathrm{Qa}_{3}$ only slowly increases (see inset Figure 6b). It appears then that $\mathrm{a}_{5}$ and $\mathrm{a}_{4}$ signals might be related to mass transport limited processes associated with metallic indium dissolution. An hypothesis that can be made is that $a_{4}$ and as signals could be related to the formation of species limited by chloride ions mass transport, like $\mathrm{In}_{\mathrm{x}} \mathrm{Cl}_{\mathrm{y}}{ }^{3 \mathrm{x}-\mathrm{y}}$ complexes. Indeed, these electrochemical processes cannot be observed when using chloride-based RTILs [22,25] or high temperature molten salts $[23,24,28]$ in which chloride mass transport is not limiting, as chloride ions are 
not present as solutes but as part of the solvent. It must be kept in mind that RTIL are viscous media in which mass transport is very slow. The hypothesis of a limitation by chloride ions mass transport is also comforted by the diffusional shape of as signal. The same hypothesis could also explain that $c_{2}$ and $c_{5}$ cathodic signals are both related to $\operatorname{In}(0)$ deposition and could correspond to the reduction of several In(III) - based species.

\subsection{Influence of chloride ions on $\operatorname{In}(I I I) / \operatorname{In}(0)$ electrochemical behavior}

\subsubsection{In(III) electrochemical behavior in a chloride-free electrolyte}

In order to validate the previous hypothesis concerning the influence of $\mathrm{Cl}^{-}$ions on $\mathrm{In}(\mathrm{III})$ electrochemical behavior, a chloride-free electrolytic solution was studied. In(III) ions were introduced in the RTIL by potentiostatic oxidation of an In soluble anode. The counter electrode was isolated in a salt bridge to avoid electrolyte degradation. The concentration of In(III) species was calculated by the mass loss of the soluble anode. A typical cyclic voltammogram of the resulting solution is given in Figure 7.

Figure 7: Cyclic voltammogram of a $1.87 \times 10^{-2} \mathrm{M}$ In(III) solution of chloride-free BEPipTf ${ }_{2} \mathrm{~N}$. Scan rate $5 \mathrm{mV} / \mathrm{s} . \mathrm{T}=60^{\circ} \mathrm{C}$. Pt substrate.

A very simple voltammogram is obtained compared to those previously recorded using $\mathrm{InCl}_{3}$. A single electrochemical system is observed, with a nucleation loop at $-70 \mathrm{mV}$ vs $\mathrm{AgCl} / \mathrm{Ag}$, characteristic of a metallic deposition process. This voltammogram is very similar to the one obtained using $\mathrm{InCl}_{3}$ in chloride-based electrolytes [22-25,28] and is characteristic 
of a single species in solution. In chloride-based RTIL, In(III) exists solely as $\mathrm{In}_{2} \mathrm{Cl}_{5}{ }^{2-}$. In our case, $\operatorname{In}(\mathrm{III})$ may exist as $\operatorname{In}^{3+}$ or $\operatorname{In}_{\mathrm{x}}\left(\mathrm{Tf}_{2} \mathrm{~N}\right)_{\mathrm{y}}{ }^{3 \mathrm{x}-\mathrm{y}}$.

XRD/SEM-EDS analysis of potentiostatic deposits confirmed the presence of metallic In for deposition potential values lower than $-80 \mathrm{mV}$ vs $\mathrm{AgCl} / \mathrm{Ag}$.

\subsubsection{Influence of $\mathrm{Cl}^{-}$concentration on the electrochemical behavior of $\operatorname{In}(\mathrm{III})$ in BEPipTf ${ }_{2} \mathrm{~N}$}

The influence of $\mathrm{Cl}^{-}$concentration on the electrochemical behavior of $\mathrm{In}(\mathrm{III})$ was studied by adding increasing amount of a chloride-based RTIL in the previously prepared chloride-free In(III) solution. Figures 8a-d presents the corresponding voltammograms recorded at the $\mathrm{Pt}$ electrode.

Figure 8: Cyclic voltammograms of a $1.87 \times 10^{-2} \mathrm{M} \operatorname{In}(\mathrm{III})$-containing BEPipTf ${ }_{2} \mathrm{~N}$ solution, recorded for different values of the $\left[\mathrm{Cl}^{-}\right] /[\mathrm{In}(\mathrm{III})]$ ratio. Scan rate $5 \mathrm{mV} / \mathrm{s} . \mathrm{T}=60^{\circ} \mathrm{C}$. $\mathrm{Pt}$ substrate.

As can be observed, as soon as $\mathrm{Cl}^{-}$ions are introduced in the $\mathrm{In}(\mathrm{III})$ solution, a second electrochemical system appears, characterized by a cathodic peak at $-850 \mathrm{mV}$ vs $\mathrm{AgCl} / \mathrm{Ag}$ and a corresponding anodic peak at $-800 \mathrm{mV}$ vs $\mathrm{AgCl} / \mathrm{Ag}$ (Figure 8a). This electrochemical system progressively shifts towards more cathodic potential values as $\mathrm{Cl}^{-}$concentration increases (Figure 8b-c). Corresponding peak currents increase with $\mathrm{Cl}^{-}$concentration and one can observe the simultaneous decrease of peak currents related to "free"-In(III)/In(0) system. This behavior reveals the presence of indium chloride species $\operatorname{In}_{x} \mathrm{Cl}_{y}{ }^{3 x-y}$. By overlaying the cyclic voltammogram recorded in a $\mathrm{InCl}_{3}$ - containing electrolyte of identical $\mathrm{In}$ (III) concentration, it appears that the electrochemical signals $c_{5} / a_{5}$ correspond to an $\operatorname{In}_{\mathrm{x}} \mathrm{Cl}_{\mathrm{y}}{ }^{3 \mathrm{x}-}$ 
y/In(0) electrochemical system (Figure 8d). One can also conclude from these experiments that the electrochemical signals $c_{2} / a_{3}$ correspond to the "free" $\operatorname{In}(\mathrm{III}) / \operatorname{In}(0)$ system. The exact formula of the chloride complex could not be determined as cyclic voltammograms are affected by the progressive increase of electrolyte viscosity with chloride-based RTIL addition. This could also explain that the voltammogram recorded for a $\left[\mathrm{Cl}^{-}\right] /[\mathrm{In}(\mathrm{III})]$ ratio of 3 does not match, in terms of peak intensities, with the voltammogramm corresponding to the $\mathrm{InCl}_{3}$ - containing electrolyte.

These experiments highlight the formation of indium-chloride complex species during the running of a cyclic voltammetry experiment. This phenomenon can be explained by the changes in interfacial relative concentrations of $\mathrm{In}(\mathrm{III})$ and $\mathrm{Cl}^{-}$species during the cathodic/anodic scans, due to $\operatorname{In}(\mathrm{III})$ consumption/formation. When the cathodic scan progresses, $\operatorname{In}(0)$ deposition occurs and the interfacial ratio $\left[\mathrm{Cl}^{-}\right] /[\operatorname{In}(\mathrm{III})]$ increases leading to the formation of $\operatorname{In}_{\mathrm{x}} \mathrm{Cl}_{\mathrm{y}}{ }^{3 \mathrm{x}-\mathrm{y}}$ species that are reduced at more cathodic potentials. At the beginning of the forward scan, the ratio $\left[\mathrm{Cl}^{-}\right] /[\operatorname{In}(\mathrm{III})]$ is high and the stripping of $\operatorname{In}(0)$ previously deposited leads first to the formation of an indium-chloride complex. The interfacial ratio $\left[\mathrm{Cl}^{-}\right] /[\operatorname{In}(\mathrm{III})]$ then decreases and $\operatorname{In}(0)$ stripping reaction leads to the formation of "free"-In(III). This hypothesis is confirmed by deposition/stripping experiments (Figure 6): as the amount of deposited $\operatorname{In}(0)$ increases, as peak reaches a constant value related to the limiting mass transport of $\mathrm{Cl}^{-}$species, whereas a $\mathrm{a}_{3}$ peak increases.

These multiple electrochemical processes are due to the use of a $\mathrm{Tf}_{2} \mathrm{~N}$-based electrolyte associated to a chloride-based metallic precursor. The same electrochemical behavior could be observed with any metallic ion that may form complex species with the counter-anion of its metallic precursor salt. It has already been observed for $\mathrm{SeCl}_{4}$-containing RTILs: a single 
electrochemical system was observed by Dale et al. [22] in a chloride-based RTIL whereas Zein el Abedin et al. [14] recorded a very complex voltammogram in a $\mathrm{Tf}_{2} \mathrm{~N}$-based RTIL.

More experiments would be necessary to completely understand the electrochemical behavior of $\mathrm{InCl}_{3}$ containing $\mathrm{Tf}_{2} \mathrm{~N}$-based $\mathrm{RTIL}$, as some electrochemical signals cannot obviously be explained by the presence of chloride ions.

\subsection{Electrochemical deposition of In}

Indium electrodeposition was performed under potentiostatic conditions using both $\mathrm{InCl}_{3}-$ containing electrolytes and chloride-free electrolytes containing In(III) species introduced by anodic dissolution of an In anode. Using $\mathrm{InCl}_{3}$ - containing RTILs, deposition experiments were only conducted in the potential range corresponding to the bulk deposition of $\operatorname{In}(0)$ (around $c_{5}$ signal). In both cases, the following deposition potential values were tested: $E_{1 / 2}$, $E_{\text {peak }}$ and $\left(E_{\text {peak }}+100 \mathrm{mV}\right)$. Each deposit was analyzed by XRD and SEM-EDS. The faradic yield of each electrodeposition process was evaluated by AAS after chemical dissolution of the deposit in $\mathrm{HNO}_{3} 3 \mathrm{M}$.

Adherent, homogeneous and covering deposits were obtained for all experimental conditions tested (Figure 9).

Figure 9: Typical SEM micrographs of indium deposits obtained in BEPipTf 2 N. Pt substrate. 60 minutes deposition.

a: $\mathrm{BEPipTf}_{2} \mathrm{~N}+\mathrm{InCl}_{3} 9.22 \times 10^{-2} \mathrm{M} . \mathrm{E}_{\mathrm{dep}}=-920 \mathrm{mV}$ vs $\mathrm{AgCl} / \mathrm{Ag}$.

b: Chloride-free BEPipTf ${ }_{2} \mathrm{~N} . \mathrm{E}_{\mathrm{dep}}=-140 \mathrm{mV}$ vs $\mathrm{AgCl} / \mathrm{Ag} .[\operatorname{In}(\mathrm{III})]=7.31 \times 10^{-2} \mathrm{M}$. 
For each deposit, XRD analysis confirmed the presence of metallic In on the platinum substrate. Average faradic yields obtained for each applied potential are presented in Table 2 .

Table 2: Electrodeposition of indium on platinum in $\mathrm{BEPipTf}_{2} \mathrm{~N}$ : average faradic yields.

The highest faradic yields were obtained in both electrolytes for $\mathrm{E}_{\text {peak }}$ deposition potential. One can notice in Table 2 that faradic yields obtained using the chloride-free electrolyte are much higher than those obtained with the $\mathrm{InCl}_{3}$ - containing solution whatever the deposition potential that was applied. This phenomenon can then be attributed to the presence of $\mathrm{Cl}^{-}$ions in the electrolyte. These low faradic yields could be related to a secondary electrochemical reaction, the non elucidated cathodic process occurring between $c_{3}$ and $c_{4}$, that lead to a consumption of metallic indium simultaneously with its bulk deposition.

Besides, the changes in the interfacial ratio $\left[\mathrm{Cl}^{-}\right] /[\mathrm{In}(\mathrm{III})]$ during deposition process, that leads to the shift of the $\operatorname{In}(0)$ deposition potential towards more cathodic values as the ratio $\left[\mathrm{Cl}^{-}\right] /[\mathrm{In}(\mathrm{III})]$ increases (Figure 8), could explain the improved morphology that was obtained in chloride-free electrolytes compared to $\mathrm{InCl}_{3}$ - containing solutions (Figure 9).

Finally, EDS spectra (Figure 10) reveal the presence of $\mathrm{Cl}$ on the deposits realised in $\mathrm{InCl}_{3}-$ containing RTILs, that could be due to chloride ions adsorption on the electrode surface, to the inclusion of chloride ions in the deposits during electrodeposition process or to the formation of chloride indium species, as showed by Carpenter et al. [29]. These species could 
also be involved in non identified electrochemical signals on the cyclic voltammogram of $\mathrm{InCl}_{3}-$ containing electrolytes (Figure 1).

Figure 10: EDS analysis of indium deposits obtained in BEPipTf ${ }_{2}$ N.Pt substrate. 60 minutes deposition. (Sample presented on Figure 9).

a: BEPipTf $_{2} \mathrm{~N}+\mathrm{InCl}_{3} 9.22 \times 10^{-2} \mathrm{M} . \mathrm{E}_{\mathrm{dep}}=-920 \mathrm{mV}$ vs AgCl$/ \mathrm{Ag}$.

b: Chloride-free BEPipTf ${ }_{2} \mathrm{~N} . \mathrm{E}_{\mathrm{dep}}=-140 \mathrm{mV}$ vs $\mathrm{AgCl} / \mathrm{Ag} .[\operatorname{In}(\mathrm{III})]=7.31 \times 10^{-2} \mathrm{M}$.

\section{Conclusion}

In the first part of this paper, we presented the synthesis and some physicochemical properties of a new low hygroscopic RTIL, 1-butyl-1ethylpiperidinium bis(trifluoromethylsulfonyl)imide $\left(\mathrm{BEPipTf}_{2} \mathrm{~N}\right)$, that allowed us to perform $\operatorname{In}(0)$ ECD without the need of a glove box.

The analytical study of the second part reveals the strong influence of $\mathrm{Cl}^{-}$ions on the electrochemical behavior of In(III). The formation of indium chloride complexes due to the changes of concentrations ratio $\left[\mathrm{Cl}^{-}\right] /[\operatorname{In}(\mathrm{III})]$ of interfacial species during $\mathrm{In}(\mathrm{III})$ reduction reaction is highlighted. The formation of these multiple In-based species results in very complex voltammograms and to a real difficulty to optimize ECD experimental conditions. Another consequence, which is presented in the third part of this paper, is the important decrease of the faradic yield corresponding to $\mathrm{In}(\mathrm{III}) \mathrm{ECD}$ in the presence of $\mathrm{Cl}^{-}$ions. EDS analysis also reveals the presence of chlorine that may be whether included in the deposits or correspond to non metallic In-based compounds. 
This study shows that one must be very careful when using chloride metallic salts in $\mathrm{Tf}_{2} \mathrm{~N}-$ based RTIL, especially for metallic ions that form stable chloride complexes, for example In(III), Se(IV), Te(IV) or Ga(III). These RTIL are very popular among electrochemists' community because of their low viscosity, their high electrochemical stability and their low hygroscopic character. However, the use of a $\mathrm{Tf}_{2} \mathrm{~N}$-based electrolyte associated to a chloridebased metallic precursor can lead to complex electrochemical systems and consequently be prejudicial to ECD processes.

\section{Acknowledgements}

The authors gratefully acknowledge the 'Cluster Chimie' of the 'Région Rhône-Alpes' and the GNR CNRS SPDC2 for their financial supports.

\section{References}

[1] R. Piercy, N.A. Hampson, J. Appl. Electrochem. 5 (1975) 15

[2] S. Taunier, J. Sicx-Kurdi, P.P. Grand, A. Chomont, O. Ramdani, L. Parissi, P. Panheleux, N. Naghavi, C. Hubert, M. Ben-Farah, J.P. Fauvarque, J. Connolly, O. Roussel, P. Mogensen, E. Mahe, J.F. Guillemoles, D. Lincot, O. Kerrec, Thin Solid Films 480 (2005) 526

[3] Q. Liao, W.R. Pitner, G. Stewart, C.L. Hussey, G.R. Stafford, J. Electrochem. Soc. 144 (1997) 936

[4] E. G.-S. Jeng, I.W. Sun, J. Electrochem. Soc. 144 (1997) 2369

[5] S.-I. Hsiu, I.W. Sun, J. Appl. Electrochem. 34 (2004) 1057

[6] Y. Katayama, S. Dan, T. Miura, T. Kishi, J. Electrochem. Soc. 148 (2001) C102

[7] T.Tsuda, T. Nohira, Y. Ito, Electrochim. Acta 46 (2001) 1891

[8] E.R. Schreiter, J.E. Stevens, M.F. Ortwerth, R.G. Freema, Inorg. Chem., 38 (1999) 3935

[9] W.R. Pitner, C.L. Hussey, J. Electrochem. Soc. 144 (1997) 3095 
[10] J.L. Anthony, J.F. Bennecke, J.D. Holbrey, E.J. Maginn, R.A. Mantz, R.D. Rogers, P.C. Trulove, A.E. Visser, T. Welton, in: P. Wasserscheid and T. Welton (Ed.), Ionic Liquids in Synthesis, Wiley-VCH Verlag GmbH \& Co., 2002, Ch. 3

[11] G.R. Stafford and C.L. Hussey, in: R.C. Alkire and D.M. Kolb (Ed.), Advances in Electrochemical Science and Engineering, Vol. 7, Wiley-VCH, Weinheim, 2001, Ch. 6

[12] T.L. Riechel, J.S. Wilkes, J. Electrochem. Soc. 139 (1992) 977

[13] M. Gazlinski, A. Lewandowski, I. Stepniak, Electrochim. Acta 51 (2006) 5567

[14] S. Zein el Abedin, A.Y. Saad, H.K. Farag, N. Borisenko, Q.X. Liu, F. Endres, Electrochim. Acta 52 (2007) 2746

[15] A. Triolo, O. Russina, B. Fazio, G. Battista Appetecchi, M. Carewska, and S. Passerini, J. Chem. Phys. 130 (2009) 164521

[16] Z.B. Zhou, H. Matsumoto, K. Tatsumi, Chem. Eur. J. 12 (2006) 2196

[17] I. Mukhopadhyay, C.L. Aravinda, D. Borissov, W. Freyland, Electrochim. Acta 50 (2005) 1275

[18] P. Hapiot, C. Lagrost, Chem. Rev. 108 (2008) 2238

[19] H. Ohno, in: F. Endres, A.P. Abbott and D.R. MacFarlane (Ed.), Electrodeposition from Ionic Liquids, Wiley-VCH Verlag GmbH \& Co., 2008, Ch. 3

[20] S. Zein El Abedin, N. Boressinko, F. Endres, Electrochem. Comm. 6 (2004) 510

[21] J. Salminen, N. Papaiconomou, R.A. Kumar, J.M. Lee, J. Kerr, J. Newman, J.M. Prausnitz, Fluid Phase Equilib. 261 (2007) 421

[22] D.D. Shivagan, P. J. Dale, A.P. Samantilleke, L.M. Peter, Thin Solid Films 515 (2007) 5899

[23] Y. Castrillejo, M.R. Bermejo, A.M. Martinez, C. Abejon, J. Appl. Electrochem. 29 (1999) 65

[24] M. Mohamedi, S. Martinet, J. Bouteillon, J.C. Poignet, Electrochim. Acta 44 (1998) 797 
[25] M.-H. Yang, M.-C. Yang, I.-W. Sun, J. Electrochem. Soc. 150 (2003) C544[26] J.S.-Y.

Liu, I.W. Sun, J. Electrochem. Soc. 144 (1997) 140

[27] R.E. Visco, J. Electrochem. Soc. 112 (1965) 932

[28] M. Mohamedi, J. Bouteillon, J.C. Poignet, Electrochim. Acta 41 (1996) 1495

[29] M.K. Carpenter, M.W. Verbrugge, J. Mater. Res. 9 (1994) 2584 
Figures

Figure 1

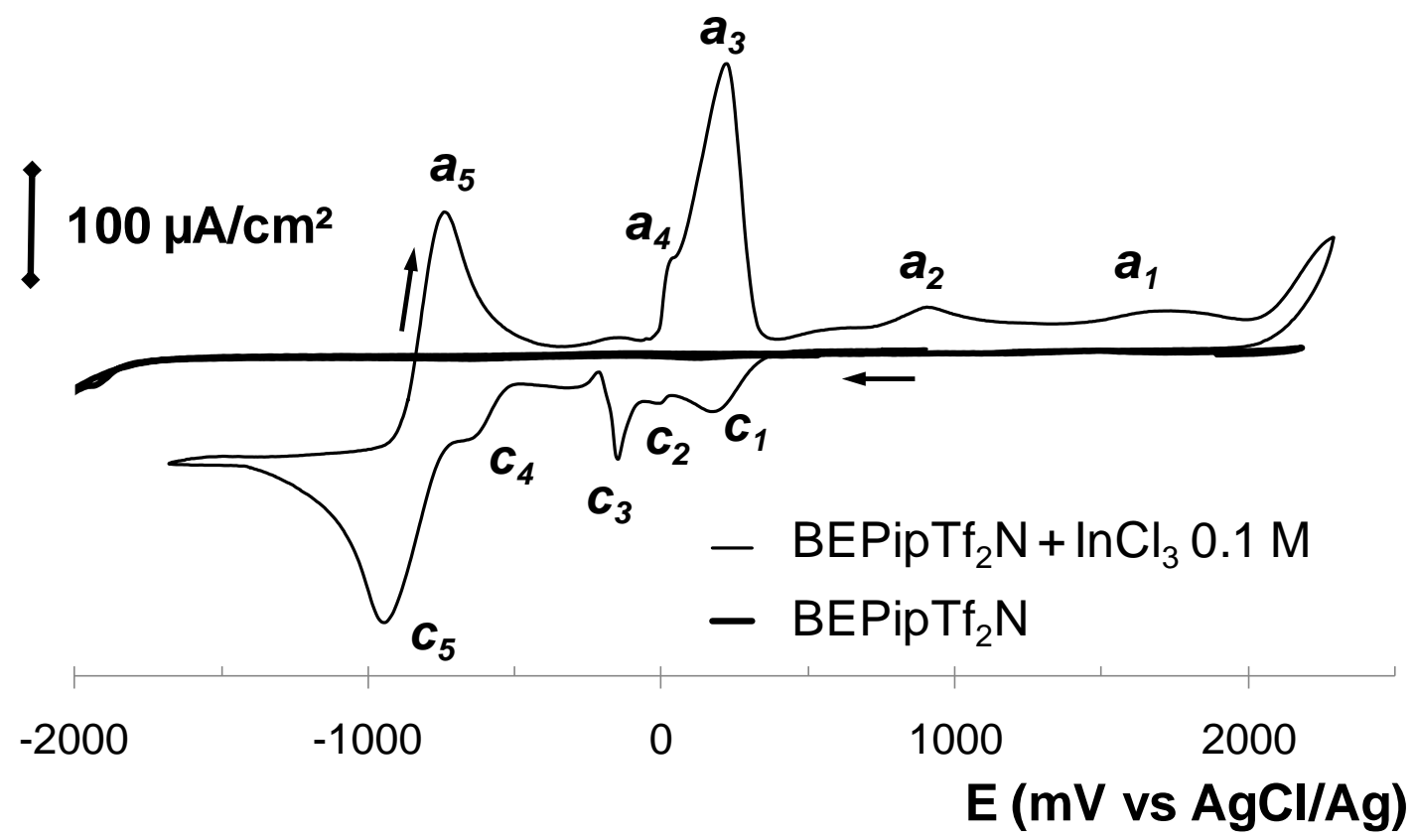

Figure 2

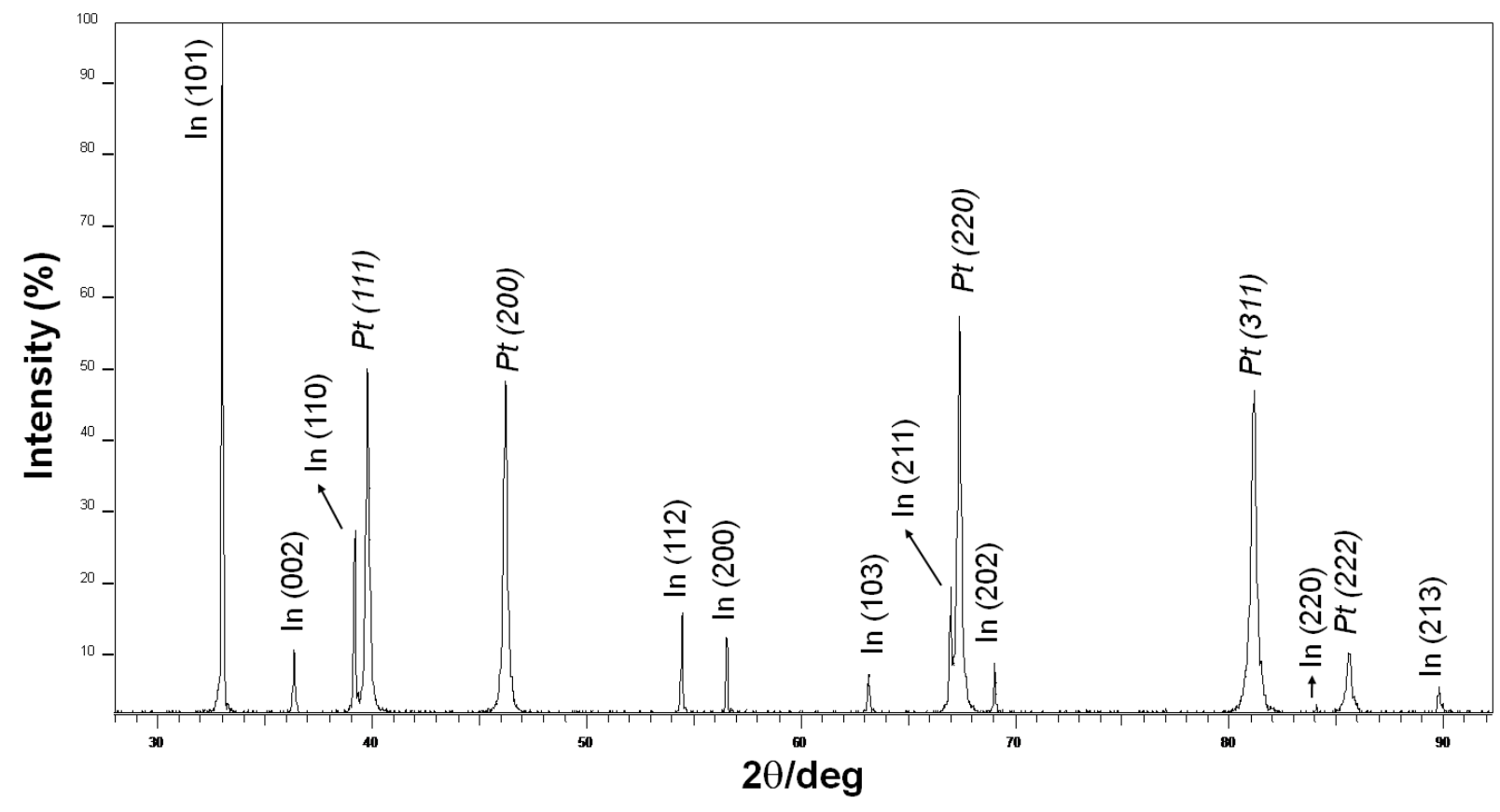


Figure 3
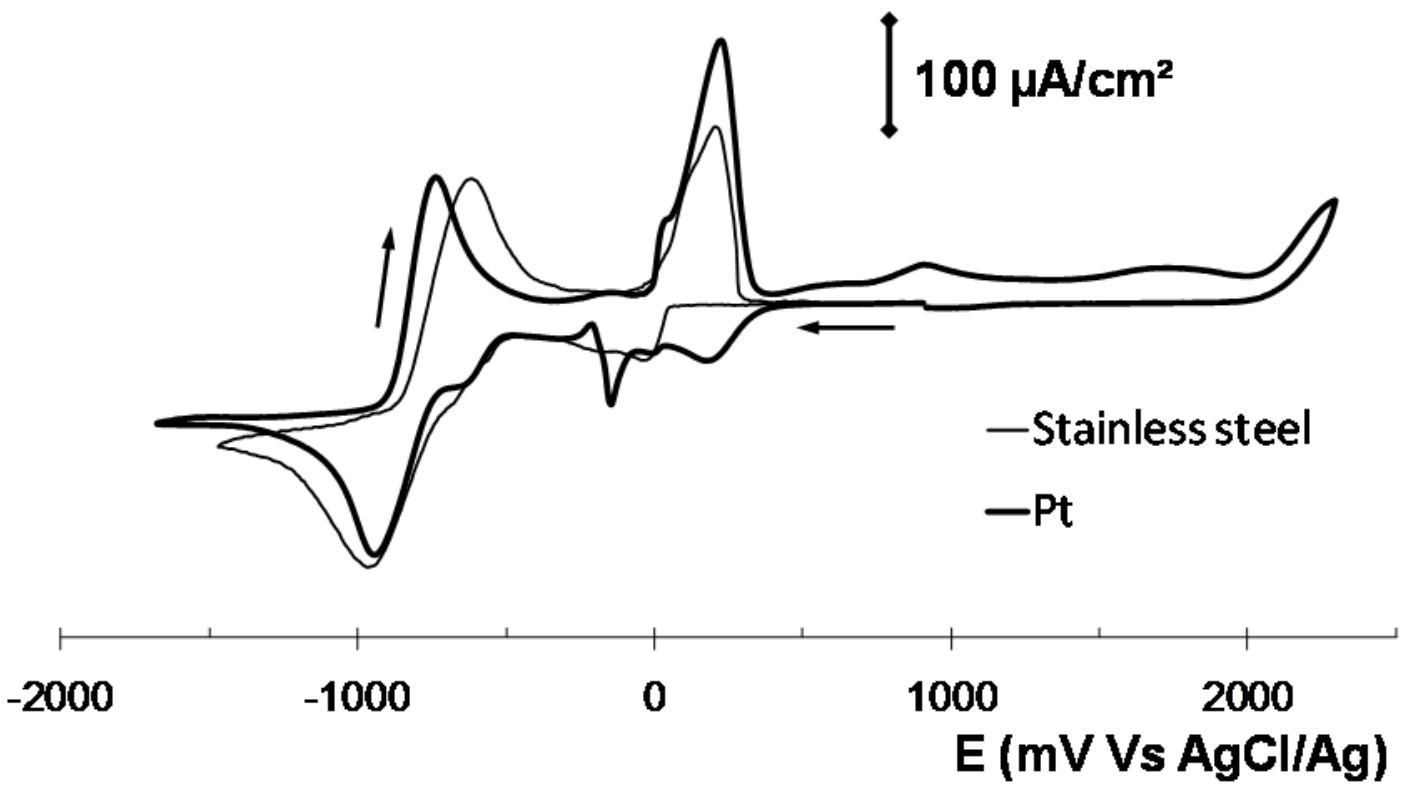

Figure 4
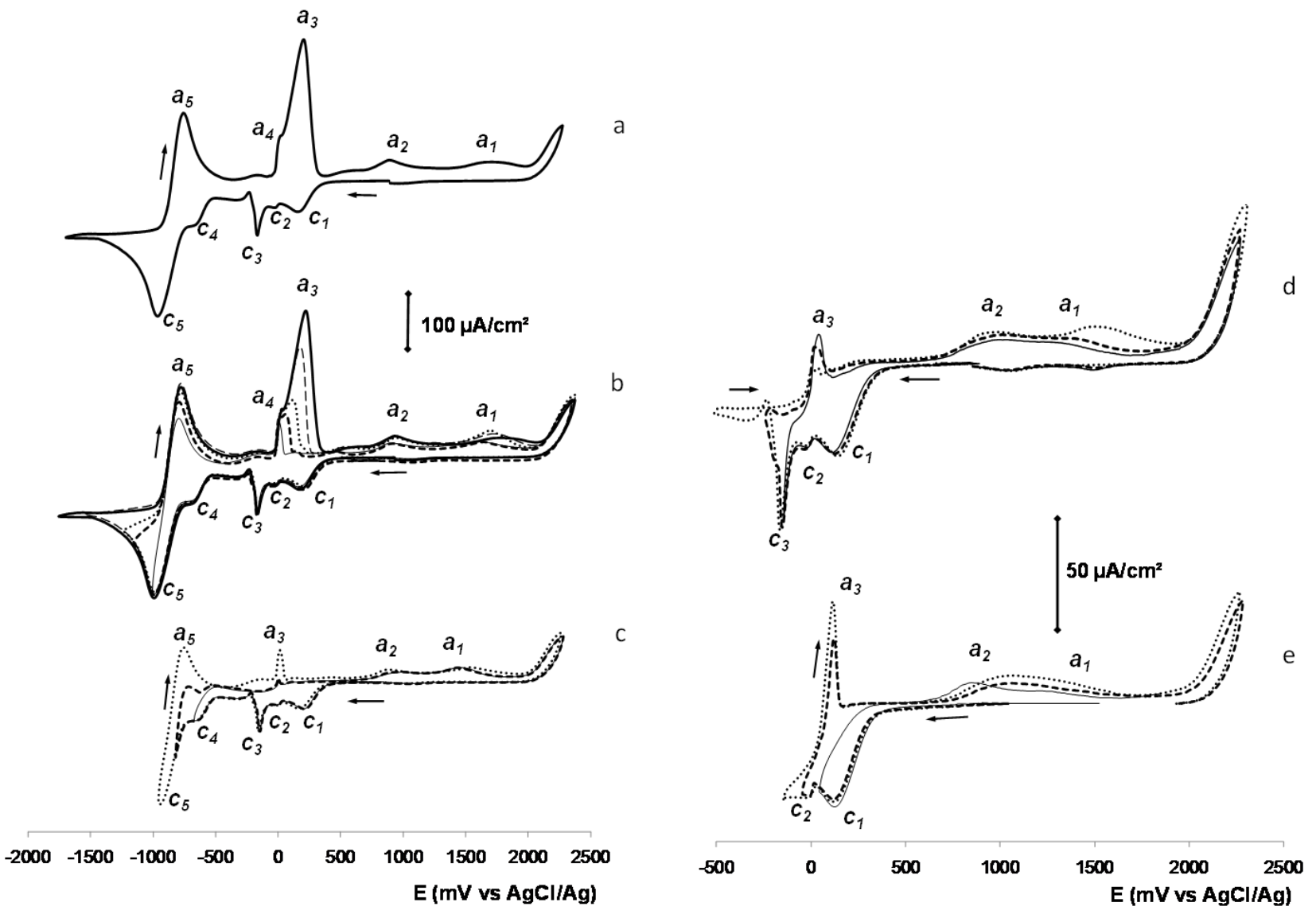
Figure 5
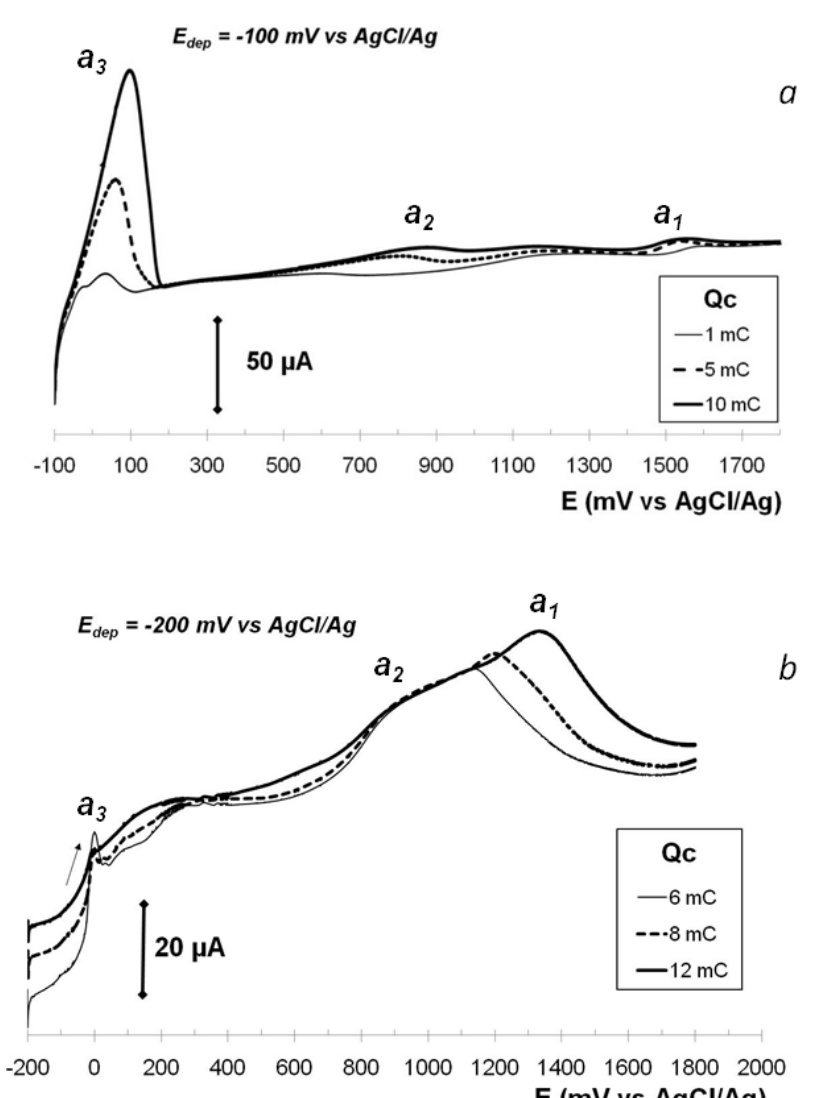
Figure 6a

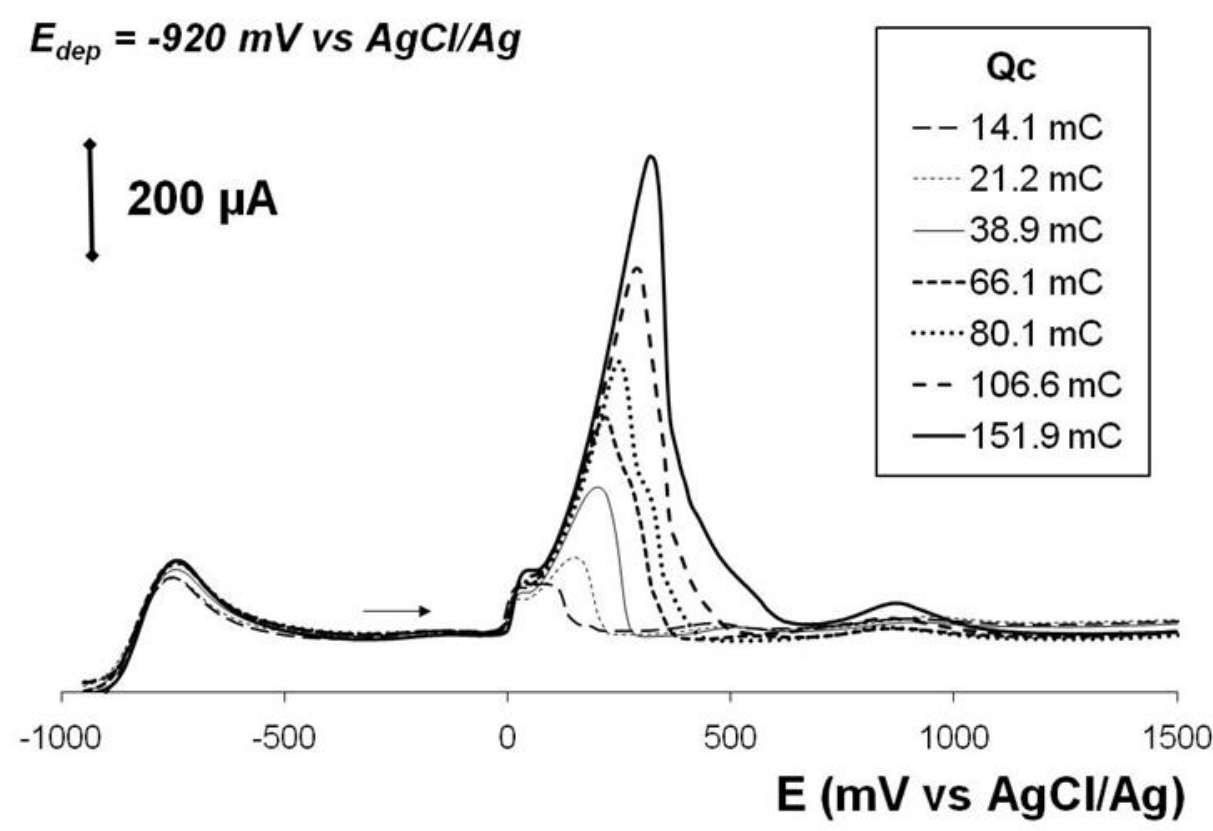

Figure $6 b$

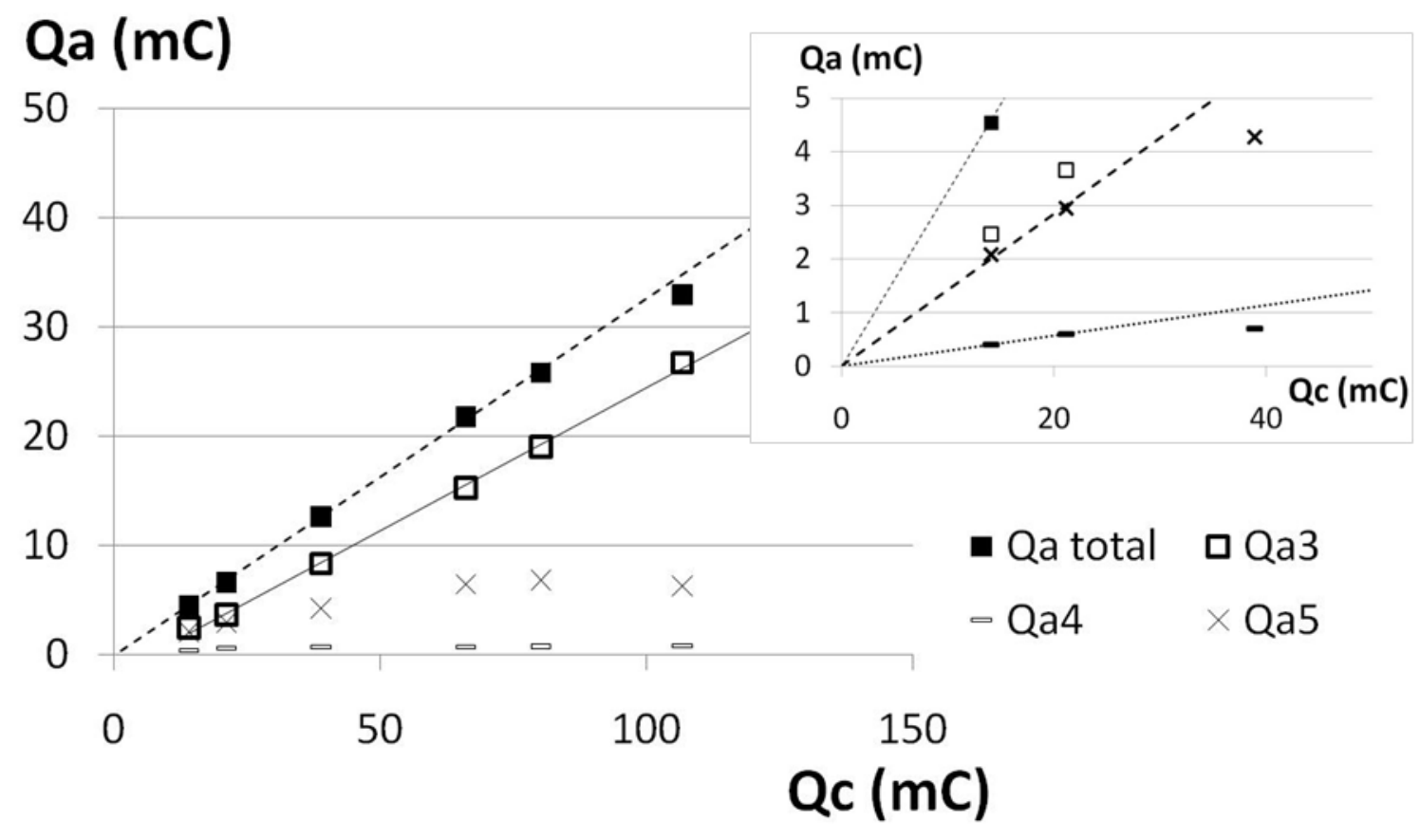


Figure 7

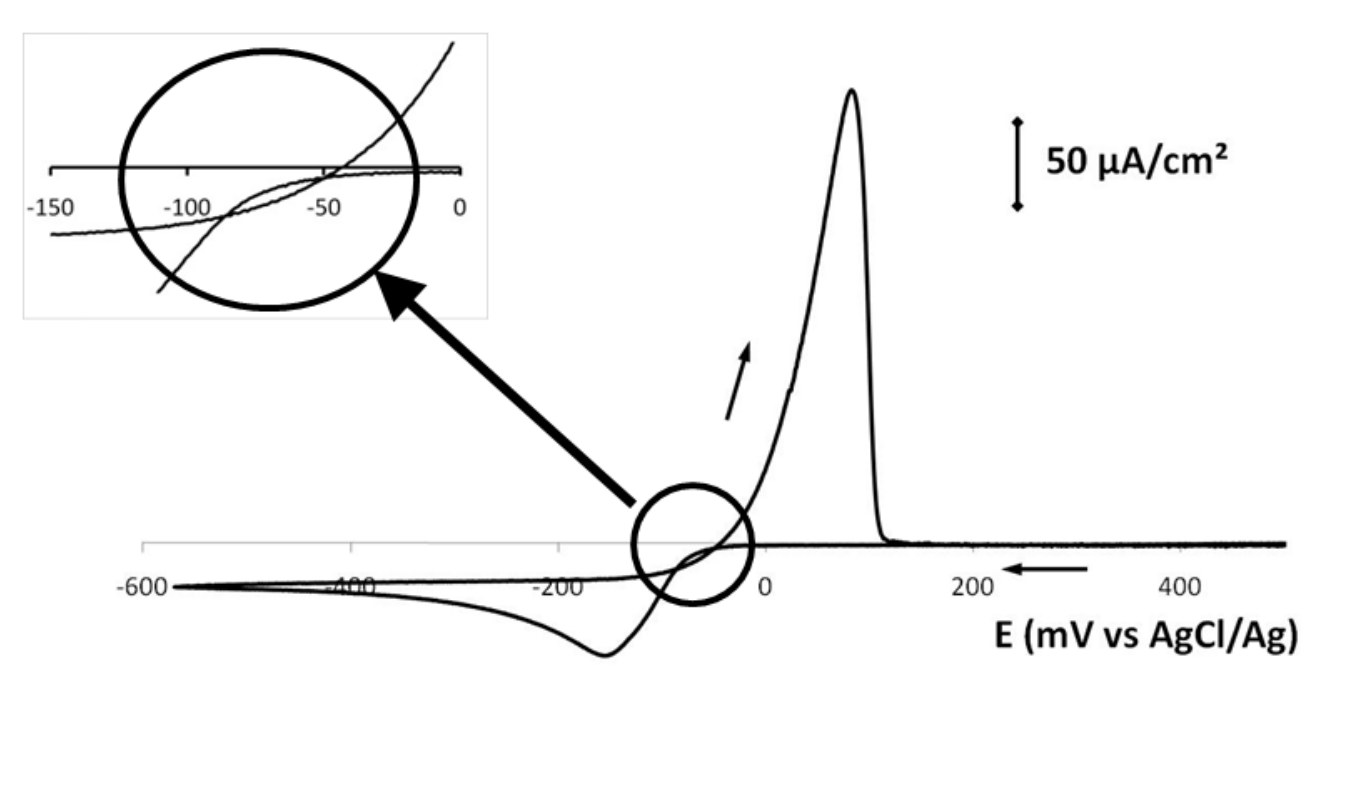

Figure 8
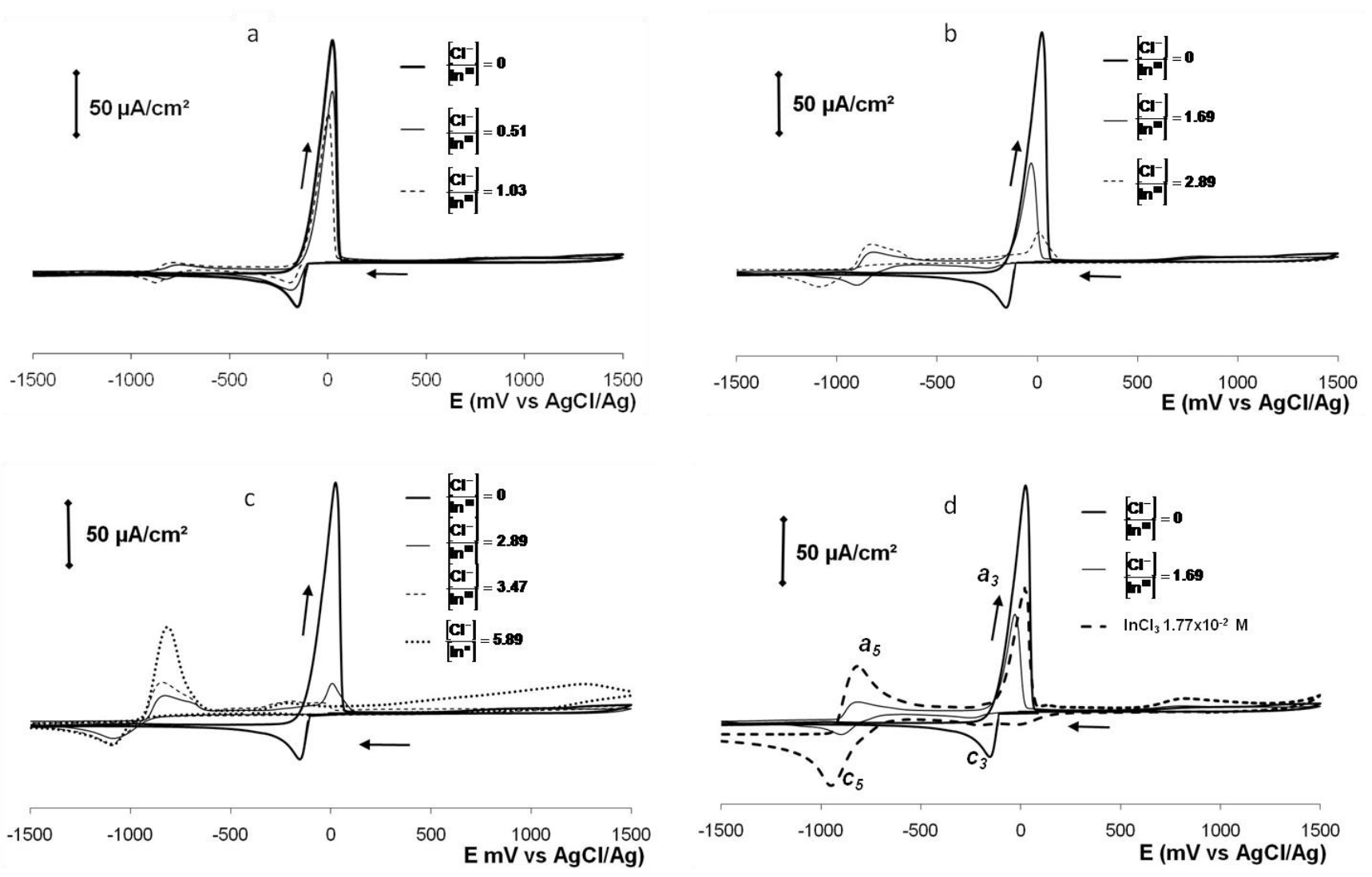
Figure 9

InCl ${ }_{3}$-containing RTIL

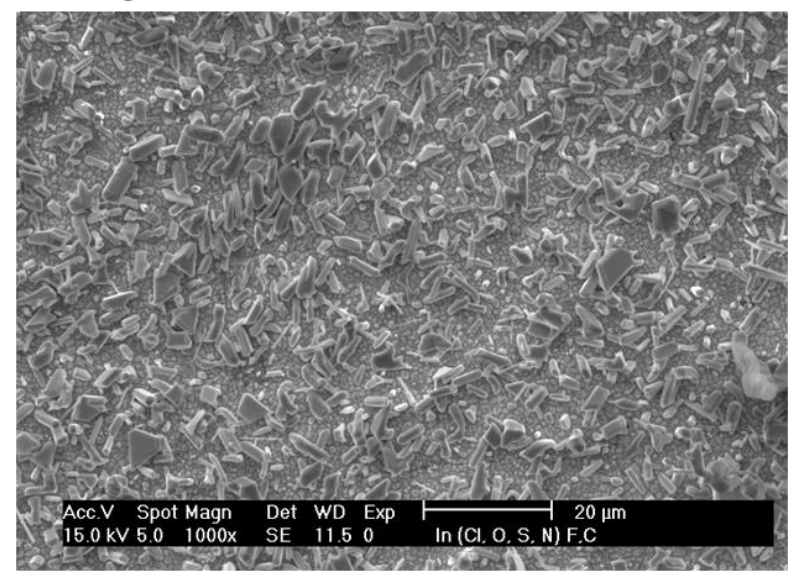

Figure 10

$\mathrm{InCl}_{3}$-containing $\mathrm{RTIL}$

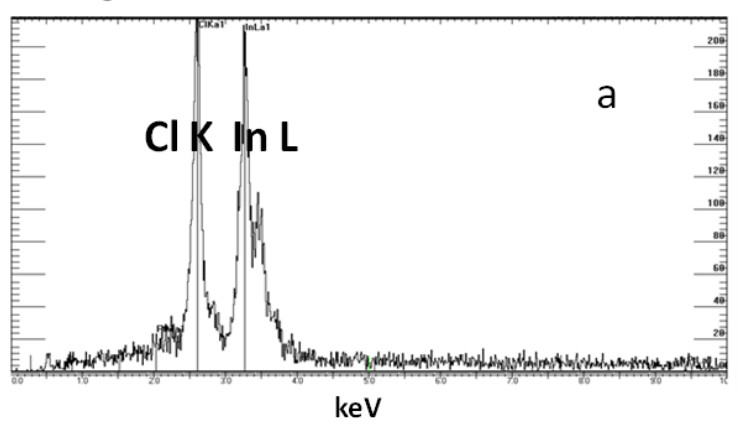

" Chloride-free RTIL »

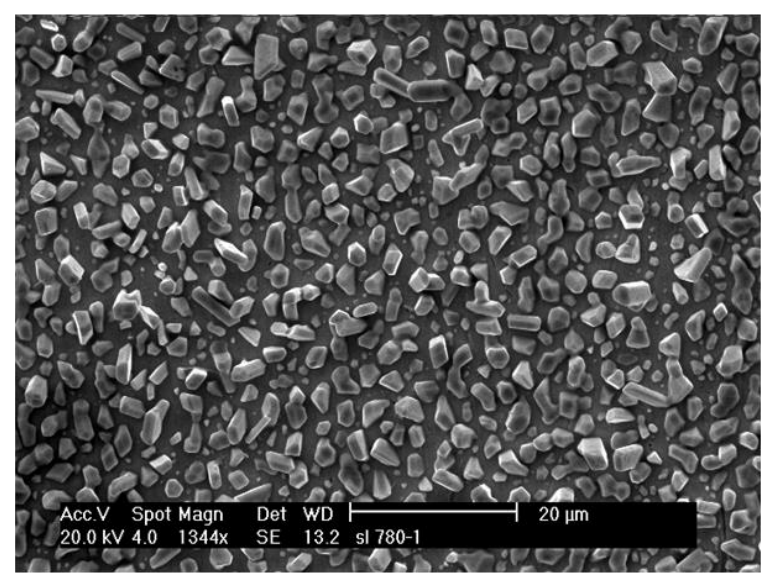

" Chloride-free RTIL "

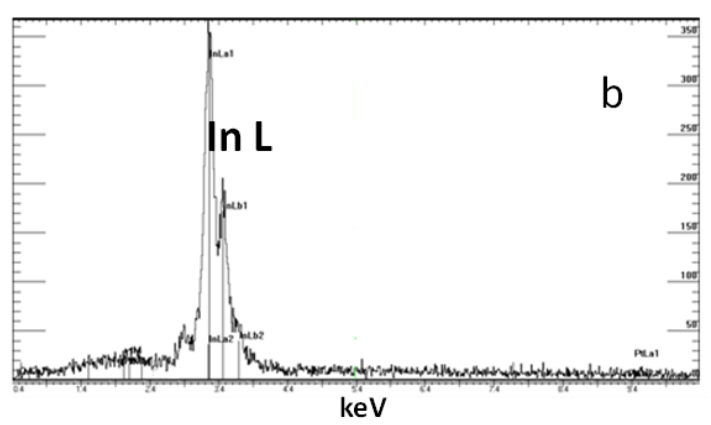




\section{Figures and Tables captions}

Table 1: RTILs physicochemical properties

Figure 1: Cyclic voltammograms recorded on platinum in BEPipTf ${ }_{2} \mathrm{~N}$.Scan rate $5 \mathrm{mV} / \mathrm{s}$. T $=60^{\circ} \mathrm{C}$.

Figure 2: XRD pattern of an indium deposit on a platinum substrate. BEPipTf $2 \mathrm{~N}+\mathrm{InCl}_{3} 0.1$ M. $\mathrm{E}_{\mathrm{dep}}=-920 \mathrm{mV}$ vs $\mathrm{AgCl} / \mathrm{Ag}, \mathrm{t}_{\mathrm{dep}}=1 \mathrm{~h} . \mathrm{T}=60^{\circ} \mathrm{C}$.

Figure 3: Cyclic voltammograms recorded in $\mathrm{BEPipTf}_{2} \mathrm{~N}$ containing $0.1 \mathrm{M} \mathrm{InCl}_{3}$ on platinum and stainless steel. Scan rate $5 \mathrm{mV} / \mathrm{s}$. T $=60^{\circ} \mathrm{C}$.

Figure 4: Cyclic voltammograms recorded on platinum in $\mathrm{BEPipTf}_{2} \mathrm{~N}$ containing $0.1 \mathrm{M} \mathrm{InCl}_{3}$ with different reversal potentials. Scan rate $5 \mathrm{mV} / \mathrm{s} . \mathrm{T}=60^{\circ} \mathrm{C}$.

Figure 5: Voltammograms recorded during anodic stripping of indium in BEPipTf ${ }_{2} \mathrm{~N}$ containing $0.1 \mathrm{M} \mathrm{InCl}_{3}$, for different deposition charge values. Platinum substrate. Scan rate 5 $\mathrm{mV} / \mathrm{s} . \mathrm{T}=60^{\circ} \mathrm{C} . \mathrm{a}: \mathrm{E}_{\text {dep }}=-100 \mathrm{mV}$ vs $\mathrm{AgCl} / \mathrm{Ag}, \mathrm{b}: \mathrm{E}_{\text {dep }}=-200 \mathrm{mV}$ vs $\mathrm{AgCl} / \mathrm{Ag}$ 
Figure 6a: Voltammograms recorded during anodic stripping of indium in $\mathrm{BEPipTf}_{2} \mathrm{~N}$ containing $0.1 \mathrm{M} \mathrm{InCl}_{3}$, for different deposition charge values. Platinum substrate. Scan rate 5 $\mathrm{mV} / \mathrm{s} . \mathrm{T}=60^{\circ} \mathrm{C} . \mathrm{E}_{\mathrm{dep}}=-920 \mathrm{mV}$ vs $\mathrm{AgCl} / \mathrm{Ag}$.

Figure 6b: Anodic charges corresponding to potentiodynamic stripping of indium (voltammograms presented in Fig. 6a) as a function of cathodic charge related to potentiostatic deposition. BEPipTf $2 \mathrm{~N}$ containing $0.1 \mathrm{M} \mathrm{InCl}_{3}$.Platinum substrate. $\mathrm{T}=60^{\circ} \mathrm{C}$. $\mathrm{E}_{\text {dep }}=-920 \mathrm{mV}$ vs AgCl/Ag.

Figure 7: Cyclic voltammogram of a $1.87 \times 10^{-2} \mathrm{M} \operatorname{In}(\mathrm{III})$ solution of chloride-free BEPipTf ${ }_{2} \mathrm{~N}$. Scan rate $5 \mathrm{mV} / \mathrm{s} . \mathrm{T}=60^{\circ} \mathrm{C}$. Pt substrate.

Figure 8: Cyclic voltammograms of a $1.87 \times 10^{-2} \mathrm{M} \operatorname{In}(\mathrm{III})$-containing BEPipTf $\mathrm{N}_{2}$ solution, recorded for different values of the $\left[\mathrm{Cl}^{-}\right] /[\mathrm{In}(\mathrm{III})]$ ratio. Scan rate $5 \mathrm{mV} / \mathrm{s} . \mathrm{T}=60^{\circ} \mathrm{C}$. $\mathrm{Pt}$ substrate.

Figure 9: Typical SEM micrographs of indium deposits obtained in BEPipTf ${ }_{2} \mathrm{~N}$. Pt substrate. 60 minutes deposition. a: BEPipTf $2 \mathrm{~N}+\mathrm{InCl}_{3} 9.22 \times 10^{-2} \mathrm{M} . \mathrm{E}_{\mathrm{dep}}=-920 \mathrm{mV}$ vs $\mathrm{AgCl} / \mathrm{Ag}$, b: Chloride-free BEPipTf ${ }_{2} \mathrm{~N} . \mathrm{E}_{\mathrm{dep}}=-140 \mathrm{mV}$ vs AgCl/Ag. $[\mathrm{In}(\mathrm{III})]=7.31 \times 10^{-2} \mathrm{M}$.

Table 2: Electrodeposition of indium on platinum in $\mathrm{BEPipTf}_{2} \mathrm{~N}$ : average faradic yields. 
Figure 10: EDS analysis of indium deposits obtained in BEPipTf ${ }_{2}$ N.Pt substrate. 60 minutes deposition. (Sample presented on Figure 9). a: $\mathrm{BEPipTf}_{2} \mathrm{~N}+\mathrm{InCl}_{3} 9.22 \times 10^{-2} \mathrm{M} \cdot \mathrm{E}_{\mathrm{dep}}=-920$ $\mathrm{mV}$ vs $\mathrm{AgCl} / \mathrm{Ag}$, b: Chloride-free BEPipTf ${ }_{2} \mathrm{~N}$. $\mathrm{E}_{\mathrm{dep}}=-140 \mathrm{mV}$ vs $\mathrm{AgCl} / \mathrm{Ag}$. $[\operatorname{In}(\mathrm{III})]=7.31 \mathrm{x}$ $10^{-2} \mathrm{M}$. 


\section{Tables}

Table 1

\begin{tabular}{|c|c|c|c|c|c|c|c|}
\hline $\begin{array}{l}\text { RTIL } \\
\text { Cation }\end{array}$ & $\begin{array}{c}\text { Density } \\
\left(\mathrm{g} / \mathrm{cm}^{3}\right) \\
20^{\circ} \mathrm{C}\end{array}$ & $\begin{array}{c}\text { Electro } \\
\text { chemical } \\
\text { window } \\
\text { (V) }\end{array}$ & $\begin{array}{c}\text { Cathodic } \\
\text { stability } \\
\text { (V vs } \\
\text { AgCl/Ag) }\end{array}$ & $\begin{array}{c}\text { Conductivity } \\
\text { (mS/cm) } \\
25^{\circ} \mathrm{C}\end{array}$ & $\begin{array}{c}\text { Dynamic } \\
\text { viscosity } \\
(\mathbf{m P a . s}) \\
20^{\circ} \mathrm{C}\end{array}$ & $\begin{array}{c}\text { Kinematic } \\
\text { viscosity } \\
\left(\mathbf{m m}^{2} / \mathbf{s}\right) \\
\mathbf{2 0}^{\circ} \mathrm{C}\end{array}$ & $\begin{array}{c}\mathrm{H}_{2} \mathrm{O} \text { sat } \\
(\mathrm{ppm})\end{array}$ \\
\hline
\end{tabular}

\begin{tabular}{|c|c|c|c|c|c|c|c|}
\hline & & & 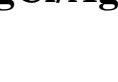 & $\left(\mathrm{ppm} \mathrm{H}_{2} \mathrm{O}\right)$ & $\left(\mathrm{ppm} \mathrm{H}_{2} \mathrm{O}\right)$ & $\left(\mathrm{ppm} \mathrm{H}_{2} \mathrm{O}\right)$ & \\
\hline $\mathrm{BMI}^{\mathrm{a}}$ & $\begin{array}{c}1.43918 \\
(2215) \\
1.429[10]\end{array}$ & $\begin{array}{c}4.3 \\
3.5[17]\end{array}$ & -1.8 & $\begin{array}{c}3.3(312) \\
4.0[18] \\
3.9[10]\end{array}$ & $\begin{array}{c}58.7(2215) \\
52[18]\end{array}$ & $40.8(2215)$ & 14990 \\
\hline $\mathrm{BMP}^{\mathrm{b}}$ & $\begin{array}{c}1.39723(537) \\
1.41[10] \\
1.393[16]\end{array}$ & $\begin{array}{c}5.1 \\
4.0[20]\end{array}$ & -2.4 & $\begin{array}{c}2.6(286) \\
2.2[10]\end{array}$ & $\begin{array}{c}97.8(537) \\
85[18] \\
76[16]\end{array}$ & 70.0 (537) & $\begin{array}{c}13123 \\
11700 \\
{[21]}\end{array}$ \\
\hline
\end{tabular}

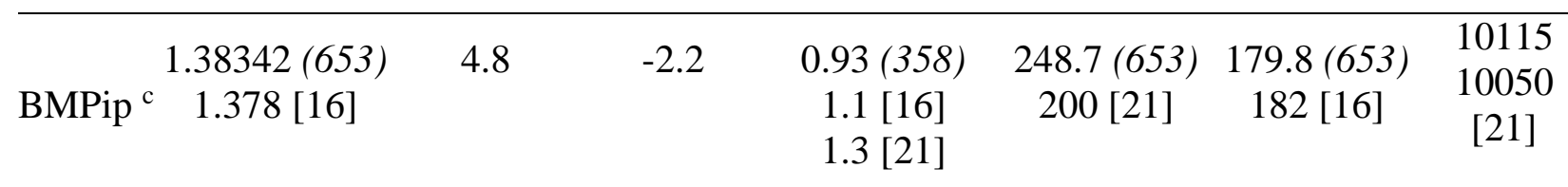

\begin{tabular}{|c|c|c|c|c|c|c|}
\hline MOPip d $^{\text {d } 1.28443(781)}$ & 5.1 & -2.4 & $0.40(315)$ & $406.9(781)$ & $316.8(781)$ & $\begin{array}{c}7961 \\
6590[21]\end{array}$ \\
\hline BEPip $^{\text {e }} 1.36623$ (415) & 4.9 & -2.4 & $0.82(150)$ & $290(415)$ & $212.4(415)$ & 10289 \\
\hline EOPip $^{f} 1.27426(721)$ & 5.3 & -2.5 & $0.34(245)$ & $423.3(721)$ & $332.2(721)$ & 7157 \\
\hline
\end{tabular}

a 1-butyl-3-methyl-imidazolium, ${ }^{\mathrm{b}}$ 1-butyl-1-methyl-pyrrolidinium, ${ }^{\mathrm{c}}$ 1-butyl-1-methylpiperidinium, d 1-methyl-1-octyl-piperidinium, ${ }^{\mathrm{e}}$ 1-butyl-1-ethyl-piperidinium, ${ }^{\mathrm{f}}$ 1-ethyl-1octyl-piperidinium

Table 2

\begin{tabular}{ccc} 
Metallic precursor & $\mathbf{E}_{\mathbf{d e p}}(\mathbf{m V}$ vs AgCl/Ag) & Yield (\%) \\
\hline \multirow{2}{*}{$\mathrm{InCl}_{3}$} & $-810\left(\mathrm{E}_{1 / 2}\right)$ & 33,7 \\
& $-920\left(\mathrm{E}_{\text {peak }}\right)$ & 35,6 \\
& -1080 & 32,2 \\
\hline \multirow{2}{*}{ In anode } & $-125\left(\mathrm{E}_{1 / 2}\right)$ & 65,5 \\
& $-140\left(\mathrm{E}_{\text {peak }}\right)$ & 85,5 \\
& -340 & 77,2
\end{tabular}

${ }_{1}^{1}$ Z.B. Zhou, H. Matsumoto, K. Tatsumi, Chem. Eur. J. 12 (2006) 2196 